\title{
"Manifold Tactics are used to Control and Prevent Pandemics in Contemporary Africa": A Case of Tanzania's Fight against COVID-19
}

\author{
Switbert R. Kamazima ${ }^{1}$, Deodatus C. V. Kakoko ${ }^{1}$ and \\ Method Kazaura ${ }^{2}$
}

\author{
${ }^{1}$ Behavioral Sciences Department, School of Public Health and Social Sciences, Muhimbili \\ University of Health and Allied Sciences, P. O. Box 65001, Dar-es-Salaam, Tanzania \\ ${ }^{2}$ Epidemiology and Biostatistics Department, School of Public Health and Social Sciences, \\ Muhimbili University of Health and Allied Sciences, P. O. Box 65001, Dar-es-Salaam,
}

Tanzania

\begin{abstract}
Since WHO declared coronavirus disease 2019 (COVID-19) a pandemic, some unprecedented measures have been adopted globally to control its transmission. Different countries, Tanzania in particularly, are using innovative ways to mitigate COVID-19 impact. The aim of this paper is, therefore, to provide an overview of strategies used to curb coronavirus spread and reducing COVID-19 impact in Tanzania. Information was collected by reviewing different documents including published papers, grey literature, newspapers, media information, formal and informal reports and discussions. Findings show that Tanzania adopted various measures including WHO recommended standard preventive behaviours and practices; spiritual healing; traditional therapies (use of traditional herbs: chewing, drinking as well as steaming). Tanzania has widely been recognized to have strongly achieved fighting COVID-19 where the use of biomedical, experience from successful battles against a number of pandemic infectious diseases, spiritual healing and medicinal herbs individually or in a combination of some sort, which is regarded to have, so far, prevented Tanzania from COVID-19 severity. We conclude, the use and importance of medicinal herbs has long roots among African societies. Traditional medicine or African therapy, therefore, is used alongside or above the modern disease management practices in most of African countries and the developing world. We recommend ongoing medicinal herbs laboratory tests in Africa and beyond should be encouraged and strengthened for the development of trustworthy,
\end{abstract}

affordable, effective and safe therapies for Africa and the world.

Key words: Coronavirus, COVID-19, medicinal herbs, traditional medicine, Tanzania

\section{Introduction}

The world is currently experiencing an unprecedented outbreak of the Coronavirus 2019 disease (COVID-19). The disease is caused by severe acute respiratory syndrome coronavirus 2 and very contagious and infectious (SARS-CoV-2) [1]. The COVID-19 was first identified in the Wuhan, Hubei Province, China, in December 2019 [2]. As the number of infected people increased in China, within no time the infection rapidly spread to other countries. Towards the end of January 2020, for the first time, the World Health Organization (WHO) declared a need to have a public health emergency of international concern. By mid-March 2020, WHO declared COVID-19 a pandemic [3]. By October 18, 2020 (07:10 GMT, COVID-19 had affected 215 countries recording 39, 964,070 case, 29,891,357 recoveries and 1,114,700 deaths [4]. Although currently there are no confirmed major breakthrough of COVID-19 treatments, there are increased multiple efforts to develop coronavirus prevention or cure $[5,6]$. Only until then, the main management of the disease will be only control of presenting disease symptoms.

Most of the initial reported cases in Africa originated from Europe and the United States but not directly 
from China. Among African countries, Egypt was the first country to report the first COVID-19 case (on February 14, 2020). Other counties like Algeria, Nigeria, Morocco and South Africa followed. By May 2020, the disease had spread in all African countries recording 100,723 cases, 57,727 active cases, 39,886 recoveries and 3,110 deaths. Lesotho was the last country on the continent to report COVID-19 case on May 13, 2020. By October 18, 2020 (07:10 GMT), Africa had recorded 1,646,896 cases, 1,352,639 recoveries and 39,622 deaths [4].

In the absence of vaccine and cure for COVID-19, there have been multiple strategies (medical and behavioral) to prevent and control its spread at the individual, family, national, regional and global levels. With the "test, trace, isolate and treat" approach, the WHO supported African countries to establish COVID-19 testing laboratories, propagated quarantining those suspected to have the disease and isolating and treating confirmed cases for at least 14 days [7]. The common recommended preventive measures include: staying at home; healthy eating; avoiding crowded places; practicing good respiratory hygiene and regular hand washing with running water and soap for at least 20 seconds. In addition, using alcohol-based hand rub; keeping physical distance; covering for coughs and sneezes with tissue or elbow; not touching faces (mouth, eyes and nose) with unwashed hands; mass face masks wearing and staying safe $[1,7]$.

Based on experience from fighting pandemics that had hit Africa in the past, such as Small pox, Black death, Chicken pox, Spanish flue, HIV and AIDS, Swine flu, Ebola and Zika, different countries deployed different preventive measures. These measures included travel restrictions within and outside the countries, international flight cancellations, event cancellations, closure of learning institutions, imposing curfews, working from home, limiting public transport, banning recreational services and border closures. However, at the individual and family levels, preventive measures to reduce chances of infection recommended by WHO include staying at home and staying safely. In this paper, we present, discuss and demonstrate multiple COVID-19 control strategies implemented in Tanzania. To achieve this objective, we collected and reviewed different documents including published papers, grey literature, newspapers, media information, formal and informal reports and discussions.

\section{Tanzania's responses to COVID-19}

Under the guidance of Tanzania's Minister for Health, Community Development, Gender, Elderly and Children (MoHCDGEC), preventive measures have been taken to control the spread of the virus. On March 16, 2020, the Minister reported the first COVID-19 case in Tanzania [8,9]. From that particular day, different strategies to help curb the spread of the deadly virus in the country started unfolding.

\subsection{Adhering to $\mathrm{WHO}$ recommendations}

Through the MoHCDGEC, the government directed the citizens to observe COVID-19 preventive measures as per WHO guidelines. Initially, the government decided to close schools and colleges. The decision to close these institutions was based on the fact that COVID-19 could be easily spread in schools and colleges due to congestions. Given anticipated negative impact of gatherings, the government also banned all political gatherings and rallies, stopped public social gathering, banned conferences and suspended the football Vodacom Premier League (VPL) and other sports activities for thirty days. The government also restricted large social gatherings like meetings, religious ceremonies that trigger gatherings and introduced temperature checks at border-entry points. The government advised all citizens to postpone non-essential travel to COVID-19-affected countries. In addition, the President postponed the Uhuru Torch ceremony, an annual event that involves relaying a torch across the country [8]. Furthermore, the Prime Minister informed the public that "the government shall review the situation pending on the development on the ground" [10].

On March 23, 2020 the Government announced that all incoming travelers from COVID-19 affected countries shall be placed on compulsory quarantine of 14 days at their own expenses. On April 11, 2020, the government halted international flights [11]. The President, however, denied the lockdown stressing, "There is not going to be any such thing as lockdown in Tanzania, God will help us ... We need to work hard ... Once the other East Africans are done with their lockdown, they will come to us, and we shall still help them with food, we will not discriminate them" [12]. Moreover, the government ordered public transport to carry passengers as per vehicles' sitting capacity. The drivers of commercial motorcycles, "boda-boda", were required to carry one passenger at a time. Worship places such as churches and mosques and other gathering places, such as restaurants and pubs remained open but were required to observe social distancing. In addition, all public places were directed to have hand washing or sanitizing materials for anyone coming in or leaving the premise. The MoHCDGEC issued a hotline number (toll-free) or Health Emergency Number 199 
for citizens to call or texting in case of symptoms. However, unlike her neighbors, the Tanzania government did not impose border closure to control the spread of the novel coronavirus. Neither did Tanzania reinforce lockdown nor curfews [13].

\subsection{Use of medicinal organic herbs purported to prevent or cure COVID-19}

Based on the experience of using medicinal herbs to prevent, treat and cure pandemics in the past, various concoctions were introduced in Tanzania and on the African continent at large to curb COVID-19. Artemesia Annua: Madagascar confirmed the first COVID-19 case on Sunday, May 17, 2020. A few hours later, the Madagascar President, addressed the nation announcing he had COVID Organics (CVO), an organic herbal beverage that could prevent or cure the virus. He urged the citizens, "Let's drink this herbal tea to protect ourselves, to protect our family and our neighbors ... and there will be no more deaths" [14]. The President launched the remedy in Antananarivo on April 20, 2020. The plant bears a name Artemesia Annua, of a Chinese origin imported to Madagascar to treat malaria in the 1970 s $[14,15]$. The mixture was developed by the Malagasy Institute of Applied Research (IMRA) and the National Pharmacology Research Center [16].

On April 20, 2020, the Madagascar President said "All trials and tests have been conducted and its effectiveness in reducing and eliminating symptoms has been proven in the treatment of COVID-19 patients in Madagascar" [17] and "This herbal tea gives results in seven days" [15]. He added that "The patients who have healed [in Madagascar] have taken no other product than COVID-Organics" [18]. African countries including the Comoros Island, Guinea Bissau, Equatorial Guinea, the Democratic Republic of Congo, Liberia, Niger, Tanzania, Nigeria, Senegal and Chad imported the medicine (CVO) [14-17,19-21]. However, WHO and the Africa Center for Disease Control and prevention (Africa CDC) declared "Madagascar's herbal tonic against COVID-19 not a cure" [22].

Tanzania received the CVO consignment on May 8, 2020 [23]. Speaking at a press conference in Dar-esSalaam on May 9, 2020, the Minister for Foreign Affairs and East African Cooperation stated Madagascar had donated the herbal mixture for clinical trials by the National Institute for Medical Research (NIMR) and other experts and not for prescriptions to patients $[21,24]$. The Minister who led a team of experts to Antananarivo, Madagascar, to collect the herbal mixture informed that, "I want to make it clear among Tanzanians that we haven't come with medicines to prescribe to COVID-19 patients. We have brought a consignment for research and analysis" [24]. Until the time of writing paper, CVO test results in Tanzania were not yet out.

In the same period, different individuals and institutions in Tanzania appealed have discovered the cure for the novel coronavirus and their number has kept increasing [25]. Prof. Hamis Malebo is one of Tanzanians claiming to have COVID-19 cure, COVIDOL, which he attests "it has been used to lower fever faster ... It fights respiratory problems, influenza and body fatigue - [signs] that emerge with the disease [COVID-19] [25]. However, the NIMR Director General warned the 'cure' needs to undergo scientific testing before allowing production for mass consumption.

The NIMR's NIMRCAF: The Director General of NIMR reported they had a nutritional mixture, NIMRCAF, of common spices and foods used by community members in the country on the daily basis that has proven to give relief to patients with COVID-19 conditions [26]. The NIMR Director of Traditional Medicine informed NIMRCAF is a mixture of pepper, ginger, lemon, gallic and hot water [27]. According to the other NIMR staff, NIMRCAF is a polyphenol rich in vitamin $\mathrm{C}$ and $\mathrm{K}$ that prevents blood clotting, adding, "a patient using this nutritional mixture gets relief in 30 minutes" $[27,28]$. Kimaro [27] present three witnesses (two in Dar-es-Salaam: a Resident Engineer, a lady and one in Dodoma), who had COVID-19 conditions, took NIMRCAF and have now recovered. The official noted that each patient experienced relief within half an hour after use at a dose of two tea spoons thrice a day. However, the NIMR Director of Traditional Medicine emphasized that, "NIMRCAF is not a COVID-19 cure, but it helps to clear early [COVID19 like] conditions ... NIMRCAF has no side effects and should be used for prevention ... not a cure" [27-29].

According to the NIMR Director of Traditional Medicine, NIMR initially produced 1,000 bottles of which 120-200 were distributed to patients in hospitals. "The government has given us support and the plan is to produce 5,000 bottles a day to meet increasing demand ... A half-liter bottle sells at TShs $10,000 /=$ (about 4 USD). A patient has to take two table-spoons; three times a day for five days" [2830].

\subsection{Use of medicinal herbs steaming ("Nyungu")}

Addressing the nation on April 22, 2020, the President asked the Tanzanians to follow another 
alternative cure for COVID-19, medicinal herbs steaming or Kujifukizia (Kiswahili), urging the MoHCDGEC to accentuate this practice as a way of treating the pandemic [31]. Kujifukiza is when someone covers himself/herself usually with a blanket or bed sheet, over a pot/pan or nyungu (Kiswhili) of boiled or boiling mixture of medicinal herbs to remedy the experienced/perceived ill-health condition. Describing 'kujifukizia' and its efficiency, someone wrote:

"Kujifukiza" is a traditional herbal treatment where plant leaves are boiled in water and people are covered around to inhale medicinal volatile substances. In summary, the aim of "kujifukiza" is not steam inhalation but rather "inhalation of volatile medicinal oils". These oils have variety of activities including anti-bacterial, anti-viral, and soothing. The science of what plants have what activity is in its infancy but that does not preclude their use.

Insisting on the benefits of "kujifukiza" the President recounted,

Therefore, I ask the Ministry of Health to emphasize this ... For example, the issue of steam inhalation. Scientifically, that is very clear ... That's because steam comes from boiling water at temperatures above $100^{\circ} \mathrm{C}$ ... And because the coronavirus is made up of fats, when exposed to such high temperatures above $100^{\circ} \mathrm{C}$, it will just disintegrate. It is a scientific treatment [31].

From that day, different government officials were recorded emphasizing the use of medicinal herbs steaming to curb the pandemic. The Minister for Regional Administration and Local Government Tanzania in the President's Office (PO-RALG), for example, urged Tanzanians not to be ashamed of medicinal herbs steaming that could help fight the coronavirus [32]. In the same spirit, the Rukwa RC, advised the region's inhabitants to practice medicinal herbs steaming as recommended by the national leaders [33].

A few days later, WHO and the African Center for Disease Control and Prevention (Africa CDC) officials claimed medicinal herbs steaming could not cure COVID-19 and is dangerous to use [21, 22,34,35], emphasizing, "By physically attempting this, weather at $70^{\circ} \mathrm{C}$ or $100^{\circ} \mathrm{C}$, is dangerous ... and would lead to serious burns ... as temperatures in the nose range between $32^{\circ} \mathrm{C}$ and $34^{\circ} \mathrm{C}$ " [31]. Importantly, WHO and the Africa CDC demanded evidence of the safety, efficacy and quality of traditional medicine [36]. Specifically, WHO officials stated it,

Recognizes that traditional, complementary and alternative medicine has many benefits and Africa has a long history of traditional medicine and practitioners that play an important role in providing care to populations ... Africans deserve to use medicines tested to the same standards as people in the rest of the world. Even if therapies are derived from traditional practice and natural, establishing their efficacy and safety through rigorous clinical trials is critical [37].

WHO and Africa CDC's conclusion on the use of medicinal herbs triggered heated debate on social media largely advocating the efficacy of medicinal herbs steaming among African societies and more so in the COVID-19 era. Backing the President, supporters wrote [31],

It is real what the President is saying because I'm one among the victims who got healed of the virus after steam inhalation and most of us ... Tanzanians ... have been healed after using it that way! You can try it to the infected person and you will realize that the President is right!

The other supporter remarked on the need to use indigenous knowledge and refrain from a dogma of adapting whatever is from Western by saying:

I fully agree with the President ... As Africans, we need to get used to finding local solutions. Who said what Westerners impose on us is always right? We need to train ourselves to trust our leaders and their intelligence. It's stupid of Africans to interrogate our leaders with an aim of finding faults in them. We must show that we are proud of our leaders and support them. Let's not be puppets of the West.

Another message strongly supported the use of steaming as a preventive measure to COVID-19 and remarked on the experience of using steaming in communities in that steaming has always been used without any negative repercussions. The message pointed-out that:

But, steaming in the context of Tanzania as related to Coronavirus does not imply treating the COVID-19 ... This is also misleading ... It intends to reduce the viral load during incubation period within the 
gut. It is worth noting here that the technique typifies African communities in fighting against viral-flue related diseases like 'Chikungunya' [Zika]. It has been practiced in the region repeatedly particularly in Southern Tanzania where I come from. There people are practicing steaming nearly every year. However, there isn't noticed problem relating to steaming ... We have to know that COVID-19 is not only a novice disease, but a fatal one. It is in this context that Tanzanians like other African communities are 'struggling for their survival.' If they use steaming in nonfatal flue and colds how can they wait for the smooth death?

Amidst of the debate on the use of steaming in context of COVID-19, different clarifications were made in relation to the role of streaming where the practice was deemed useful in maintaining functionality of inhalation systems of the body. It was remarked:

Listen, ... I think there is a misunderstanding in here, the steam inhalation procedure isn't intended to treat the novel virus rather steam inhalation is responsible for opening the blocked air pathways so as to allow an easy flow of air through the lungs since the steam opens up the trachea by allowing lubrication of the mucus linings dried up by the COVID-19 virus ... Also, the use of lemongrass, onions and ginger act as stimulants enabling protection from the viral infections.

Another observation was based on the long tradition of using herbal medicines in African context before Western cure was introduced. The remark went further in that the only bottleneck was traditional medicines are not well researched and documented as pointed out:

Steaming should be carefully examined as a treatment because this traditional practice has helped and cured many diseases in African societies before [and after] the arrival of white medicines, ... The only problem we have in Tanzania and Africa at large is only lack of clear and proper documentations of their practices ... Before being brainwashed by white medicine, let's focus on investigations and documentation of this practice including its duration and side effects ... and possibly how to tackle them, as far as I remember many white medicines have deadly side effects but still, we are using them to treat several diseases.

Some people also indicated that medicinal herbs steaming is not unique to Africa and they are being practiced elsewhere based on their functionality in the body as someone wrote,

Steam inhalation has been used as oriental medicine in Asia since ancient times when one has cold, coughs and flu. COVID-19 virus may bind in cells but the reason of death is not the virus bind with cells but usually due to lack of oxygen in the lungs [because] the lungs due to excessive mucus and phlegm on the lungs that blocks the airways ... Steam inhalation helps dislodge the phlegm from the lungs so breathing improves.

In context of COVID-19, discussions were also based on the rationale for using traditional herbs. Examining why Africa inhabitants would turn to this alternative, someone wrote,

However, the method has been used in the region to treat respiratory diseases and some people believe it works. In these moments when there is no cure for COVID-19, people will try anything so as to remain safe!

Embracing 'the power struggle' perspective,

someone observed,

The problem is that the west scientific world is used to ridicule any and every attempt from Africa ... Even in this [commented on] article all experts interviewed are from the same geographical area ... None from Africa!! Not coincidental! When our President called for a three-day national prayer he was scathingly criticized. Today, President Trump has also declared same national prayer day, it seems ok. We will not stop at anything in attempting any remedy that may help our people to reduce the pain from the COVID-19 crisis, physically or psychologically until a solution is found.

In the effort to resolve this controversy, however, "70 traditional medicine experts from across the continent met virtually with the WHO in mid-May and agreed that clinical trials must be conducted on all traditional medicines on the continent. And perhaps the cure for COVID-19 is right here" [20].

Testifying the power of medicinal herbs steaming to the nation on Sunday, May 17, 2020, the President informed the public that "My own son after 
contracting the virus isolated himself in his room, took lemon and ginger solution before getting well and is now doing some exercise" [14,38,39]. Confidently, the NIMR Director General confirmed medicinal herbs steam inhalation has no side effects warning, "one should ensure the steam is not so hot and should last for five minutes" [40].

During an interview with Tanzania Broadcasting Corporation 1 Television (TBC1 TV) in Dar es Salaam, the traditional medicine expert from the Institute of Traditional Medicine (ITM) of the Muhimbili University of Health and Allied Sciences (MUHAS) [41], informed the public that medicinal herbs are used in three different ways. First is steaming/inhaling steam of boiled barks and or leaves of a guava tree, eucalyptus and lemongrass. Second, is drinking the 'juice/tea' from boiled medicinal herbs (barks or leaves) of a guava tree, eucalyptus, and lemon-grass. Finally, is chewing fresh herbs (barks or leaves). However, the nomenclature of herbs, concoction contents and dosage differ with individuals, societies, the nature of experienced or perceived ill condition and the purpose of use, whether prevention or cure. By the end of May, 2020, the Tanzania Small Industry Development Organization (SIDO) had manufactured modified 'nyungu' more or less similar to the sauna that would be available countrywide at affordable price [41].

The Health Official in South Africa asserts that, "Traditional medicine is used in all countries and there's a plant in South Africa, called wormwood, that's been used for generations," adding,

There is herb which we used in my part of the land, which is called UMHLONYANE [worm wood]. UMHLONYANE is used for fevers, for flues. Where I grew up we didn't go to hospital, we used UMHLONYANE, we used a lot of that and so if you had fever as young people, we knew you'd go there and collect the stuff and use it for steaming and for drinking as a kind of tonic and bath [20].

According to [20] the South African health authorities confirm they will "not be drawn in a debate on the efficacy or otherwise of traditional medicines and cures, including the Madagascar remedy." Instead,

When we come across those kinds of remedies that people are using, we make no comment about that. We just simply say we note that they are doing it. The only difference, we get involved in as the department, as the government, is when you've got to deal with a scientific analysis of what is that herb, what is the active pharmaceutical ingredient in that herb that could be proven to scientifically, in a clinical trial, demonstrate an effect on a particular pathogen on a particular condition. In this case we are not there. So, we will leave the conversations to go on the way they are going, and we just want you to be aware, we are aware of the conversations and at a point where it is necessary to assist those countries, we will assist them [20].

\subsection{Spiritual approach: praying, repenting and fasting}

While COVID-19 forced many countries to suspend religious services, Tanzania's houses of worship remained open. The government advised its citizens to worship and pray. On April 16, 2020, the President asked the nation to "Use the three days from 17th to 19th April to pray to God who can do all to help us evade this disease ... Let us pray in our own religions and God will hear us" [42-44]. Since that time, "the President has been attending church services, telling cheering congregations that coronavirus cannot survive in the bodies of the faithful." At different times, different religious leaders have led their followers in prayers to God "to quell a 'satanic' virus that can only be cured by divine intervention" [43].

Addressing the worshipers on Sunday, May 17, 2020, the President reported that COVID-19 cases were drastically going down countrywide; suggesting God had answered the prayers. He asked the citizens to use three days from May 22-24, 2020 to thank God for this 'miracle'. Following the President's observation, on May 20, 2020, the Dar-es-Salaam (the most COVID-19-hit region in the country) Regional Commissioner (RC), quickly encouraged residents "To flood the streets [on the] weekend [Sunday, May 24, 2020] to celebrate [Adding] Make all kinds of noise as a sign of thanksgiving to show our God has won against disease and worries of death that were making us suffer"' $[42,44]$.

While there may be some blames on the churches on the spread of COVID-19 in the country, it may be worth noting that churches played a role on the pandemic prevention. Religious leaders strictly instructed their congregants to adhere to basic health guidance such as frequent hand washing with soap and running water and encouraged them to observe social distancing. In addition, religious leaders shortened church/mosque services, increased number of worshiping sessions, limited the number of 
congregants per session and instructed those participating in church services to wear masks. Most importantly, the worshipers seriously adhered to both the physical and spiritual advice given by their religious leaders. Nevertheless, some Bishops and Sheikhs suspended services in their areas since the outbreak, using social media to conduct virtual services as they connect with their communities.

\subsection{Use of social media to disseminate COVID-19 health messages}

Within a week after March 16, 2020, the MoHCDGEC through its Directorate of Preventive Services had flooded the media with COVID-19 health messages on causes, mode of transmission and recommended preventive measures. Some messages are geared at checking rumors and correcting myths. Music artists in the country joined the battle against the pandemic via the edutainment approach, producing music on coronavirus and COVID-19 in general. All Television (TV) channels and Radio Stations (in-the-country) carry messages on COVID19. Posters, brochures and fliers are found almost everywhere, mainly in urban centers. Every newspaper and Magazines published in the country have followed the same path.

\subsection{Tanzanian Political leaders' perspectives of COVID-19}

Speaking at a Press Conference in Dar-es-Salaam in late May 2020, the Chama Cha Mapinduzi's Ideology and Publicity Secretary stated the country was recoding no new COVID-19 cases and the number of patients in isolation wards in the country was drastically going down. He elucidated, "Actually, we gave COVID-19 two alternatives ... One, the disease should leave our country ... beyond our borders ... Two, it should be self-disciplined to remain here ... Truly, the virus has chosen to remain with us in a disciplined manner ... I am contented, we shall soon win the battle [against COVID-19]" (TBC TV, 2020b). However, majority of the political and religious leaders continue reminding the citizenry that the risk to the coronavirus was still high and they should continue observing recommended preventive measures. The Minister for Health, for example, once alerted Tanzanians that "Coronavirus is there and it will continue for a couple of months ... We have patients and others are dying ... We need to learn how to live with it by taking precautionary measures" [21]. In some instances, political leaders advised citizens to switch to contactless payment systems such as mobile applications and electronic bank transactions.
However, this control measure was counteracted by the Bank of Tanzania authorities' announcement that the virus cannot survive on banknotes. Hence, both modes of money transactions are used in the country.

\subsection{Shifting gears}

Since the confirmation of the first COVID-19 case in the country on March 16, 2020, the government through the Prime Minister, the Minister for Health or the Chief Government Spokesman kept informing Tanzanians on the disease progression: new confirmed cases, recoveries and deaths. The government ordered the Tanzania Communications Regulatory Authority (TCRA) arresting and prosecute whoever gives misleading COVID-19 data as per The Tanzania Communications Act, 1993. The intention was to reduce misinformation that could create and fuel COVID-19 fear among Tanzanians.

In late April 2020, the President observed that COVID-19 announcements were cultivating fear among the Tanzanians, asking, "Why aren't you reporting on maternal mortality cases or malariarelated cases ... What is so special with this disease." Following the President's observation, the last time the government provided national COVID19 data was on April 29, 2020 when confirmed COVID-19 cases had risen to 480. The Government Spokesman, told the Associated Press that "It would be impossible to cover up an outbreak ... It is unfortunate that COVID-19 has come up with lots of misinformation, propaganda and false news" [44].

From that date, the government shifted gears remaining silent on the disease progression in the country. The silence remained until on May 17, 2020 when the President provided the decreasing number of COVID-19 patients in isolation at different facilities in the country. Addressing the Muslims on Eid El Fitr on May 17, 2020 in Dodoma, the Prime Minister reported "The number of patients has gone down and we are not receiving new cases". However, he warned the Tanzanians, "The disease it still amongst us ... It has not gone away ... We should continue observing protective measures as advised by Ministry of Health" [45]. On June 1, 2020, the Minister for Health reported there were only four COVID-19 patients countrywide. The Minister, however, pleaded Tanzanians to continue observing COVID-19 good behaviors and practices. Similar advice has been echoed by the elite, religious leaders and public health personnel.

This silence raised some eyebrows among Tanzanians (the elite and common citizens alike), activists, neighboring countries, Africa CDC, WHO and the International community [42,44,46-49]. The 
Opposition leaders demanded the government should break silence after virus figures were not released since April 29. The Alliance for Change and Transparency (ACT-Wazalendo) leader, for example, demanded "The government of Tanzania shouldn't keep its citizens in the dark ... Transparency is key in the fight against the COVID19 pandemic [50]. On May 12, 2020, the ACTWazalendo party released a statement that read, in part, "We need to know what the truth is and we need to know it now ... We request that the government issues statistics on a daily basis from this day forward," [50]. On May 2, the Opposition Leader and Leader of the Opposition Wing in the House, called for the suspension of the Parliament for at least three weeks after the deaths of three Members of the Parliament of unknown causes in the previous eleven days. He associated the MPs' deaths with COVID-19 and asked for testing for all MPs, parliament staff and their family members [43].

Worried about this silence, the Head of the Africa CDC noted, "Fighting the virus is more difficult without accurate data from all member states ... We strongly call on Tanzania, encourage Tanzania, to share data in a timely fashion ... [adding] ... No country is an island [44]. The U.S. Embassy in Tanzania issued a statement, warning its citizens that "All evidence points to exponential growth of the epidemic [in Tanzania] ... [and that] ... hospitals in Dar es Salaam have been overwhelmed with COVID-19 cases ... [adding] ... Chance of contracting the virus is extremely high" $[42,44]$. The British High Commission announced a charter flight for British nationals who want to leave Tanzania [44]. Uganda and Rwanda introduced extra precautionary measures for truckdrivers transporting essential goods from Tanzania [51-53]. On May 13, 2020, Zambia temporarily closed its border with Tanzania following a spike in cases at the border town of Nakonde [53,54], and Kenya followed suit $[44 ; 53]$ on $16^{\text {th }}$, May 2020.

\section{Tanzanians' response to COVID-19}

As the Minister for Health reported the first case of COVID-19 in the country and recommended preventive measures aired, Tanzanians in the urban areas, in Dar-es-Salaam in particular, panicked taking different responses to the pandemic. The majority hasty invaded pharmacies, supermarkets, open markets and shops to stock up on food items, sugar, drinks, water, rice, flour, beans and other essentials [55]. Fear of possible food shortage spread like bush fire! Quickly, pharmacies run out of face masks and sanitizers resulting to price skyrocketing. "The price of hand sanitizers, for example, rose from US $\$ 1$ for a $100 \mathrm{ml}$ bottle to $\$ 7$... A box of gloves was going for up to $\$ 20$ while masks were completely out of stock" [55]. As the government banned crowding, social events like weddings, political gathering and religious celebrations, were either cancelled or postponed till further notice. Tanzanians somehow limited their movements and some inter-regional public transport companies suspended operations. In-town buses operated at their passenger capacity levels. School children were at home following closure of private and public institutions that required parents' attention and guidance all the time. The government required parents to monitor their children and assist them on online learning or 'Darasa online' programs (aired by Tanzania Broadcasting Cooperation [TBC] Television channel 290) and other learning materials sent online from their respective teachers and schools. The media became flooded with COVID-19 health education and promotion messages. Religious and political leaders repeatedly reminded the Tanzanians of the pandemic and, to a larger extent, conversation among citizens was around COVID-19.

Following the government's order of regular hand washing or using alcohol-based hand rub sanitizers, almost all public spaces, business areas, public transport vehicles and boda boda had buckets of chlorine-treated water and soap for hands washing and sanitizers. In early April, 2020, the Dar-esSalaam RC required every inhabitant to wear a mask while in public spaces and public transport. Passengers in private cars carrying more than one person, including the driver, had to wear masks. Beginning that week, almost all Dar-es-Salaam residents wore masks and carried sanitizers with them. The citizens avoided hand shaking or hugging salutes and adopted the "Wuhan shake feet greeting". Although worshiping places remained open, some believers decided praying at home and visiting neighbors became somehow a taboo!

Experience with the healthcare system in the country and the fact that COVID-19 has no vaccine or cure, majority of the Tanzanians searched for alternative remedies, the African therapy, including taking tea from boiled mixture of eucalyptus, ginger, lemongrass, gallic and lemon. With the President's encouragement to use nyungu, many Tanzanians, the elite and common citizens alike, embarked on kujifukiza and other remedies depending on one's background and experience. Yet others turned to prayers, fasting and retreating in search for God's mercy against the pandemic. However, with the political leaders' claims that "we have defeated the disease through prayers, a good number of urban dwellers, the Dar-es-Salaam residents in particular, sharply dropped anti-COVID-19 good behaviors and practices and life somehow returned to normal. 
Addressing the Parliament in Dodoma on Tuesday, June 16, 2020, the President announced resuming of all activities that were suspended as part of the response of COVID-19 from Monday, June 29, 2020.

\section{Discussion}

African historians and archeologists prove that before encounters with the foreign world, African societies experienced periods of hardships, deaths, drastic socioeconomic or political changes that they managed/responded to including pandemics [56,57]. Kamazima, [56], for instance, reported that before encounters with the outside world, Bahaya societies in Buhaya country in the present Kagera administrative region, Northwestern Tanzania, used different strategies to manage social, economic and political difficulties resulting from natural disasters (drought, floods, earthquakes, human and animal diseases and climatic change), manmade disasters (wars), political dissatisfactions and economic development.

The Bantu hunters, who occupied the Kagera River Valley during the early times and depended on it for their livelihoods: settlement, food, wildlife, water, and avenues of interaction, migrated to areas suitable for cultivation in Karagwe and Bukoba highlands following changes in technology (Buhaya), population growth and the emergence of agriculture. Bantu organized themselves in small clan settlements. Increased agricultural production, further technological advancement and labor specialization in isolated locations precipitated social group organizations on clan basis that later developed into Buhaya societies. Bahaya, individually, families or groups dissatisfied with the Kings migrated from one Kingdom to other parts of Buhaya, Buganda, Rwanda and Urundi [56,58].

When rinderpest hit areas west of Lake Victoria in 1890 with more impact in Karagwe where it claimed $90 \%$ of cattle, majority of the pastoralists Bahima in Buhaya whose respect and prestige depended on a number of cattle owned, committed suicide or migrated to Ankole (Uganda), Rwanda and Burundi to begin new life. Other Bahima migrated eastwards to Bukoba highlands where cattle were of less importance. White [59] informed that recurrent droughts and animal diseases that hit most of Eastern, Central and Southern Africa in 1890 and the early 1900s, impacted most of the Bahaya (cultivators and the pastoralists) leading both men and women to search for food within and outside their societies. Previously, searching for food was a males' responsibility. The pastoralists Akamba, in the present Kenya, pawned women and children in exchange for food from the cultivators, the Kikuyu.

From archaeological and historical evidence [settlement layout, burials, funerary remains and human skeletons] reveals that ancient African communities adopted various strategies to manage pandemics. These included,

Burning settlements as a disinfectant before either reoccupying them or shifting homesteads [or abandoning settlement] to new locations as it was in Akrokrowa in Ghana during the early 14th century AD ... We know that social distancing formed a critical part of managing pandemics in historical African societies ... In what is Zimbabwe today, the Shona people in the $17^{\text {th }}$ and $18^{\text {th }}$ centuries isolated those suffering from infectious diseases - such as leprosy - in temporary residential structures. This meant that very few people could come into contact with the sick. In some cases, corpses were burnt to avoid spreading the contagion [57].

Emphasizing the role of social distancing in managing diseases and pandemics among ancient African societies, [57],

The layout of settlements was also important. In areas such as Zimbabwe and parts of Mozambique, for instance, settlements were dispersed to house one or two families in a space. This allowed people to stay at a distance from each other - but not too far apart to engage in daily care, support and cooperation. While social coherence was the glue that held society together, social distancing was inbuilt, in a supportive way. Communities knew that outbreaks were unpredictable but possible, so they built their settlements in a dispersed fashion to plan ahead [57].

What is important to note, is that,

There were multiple long-term implications of pandemics in these communities. Perhaps the most important was that people organized themselves in ways that made it easier to live with diseases, managing them and at the same time sticking to the basics such as good hygiene, sanitation and environmental control. Life did not stop because of pandemics: populations made decisions and choice to live with them [our emphasis] [57]. 
Chirikure [57] affirms that social distancing and quarantine were used in Medieval Times to fight the most fatal pandemic recorded in human history, Black Death, that claimed 75 to 200 million people in Eurasia and North Africa in the second half of the $14^{\text {th }}$ century (1346-1353) [60,61]. Societies used lived experience and available resources to fight pandemics, sometimes on a trial-and-error basis, which defines health seeking behavior "any action or inaction undertaken by individuals who perceive themselves to have a health problem or to be ill for the purpose of finding an appropriate remedy". COVID-19 is not quite different. In the absence of biomedical vaccine or treatment, different societies have taken different paths in the COVID-19 war. Long and deep-rooted experience and recognized effectiveness of medicinal herbs, suggest that societies in Africa and the Far East will continue using traditional therapy and biomedical treatment concurrently to restore and sustain their health.

In the developed world with fully developed healthcare systems, the American government, for example, authorized administering Hydrocloroquine to COVID-19 patients that WHO recommends for malaria treatment not COVID-19. The fragility of the healthcare system in Africa and other developing countries in general, cannot be overemphasized. Hence, mandating Africans to abide to and wait for western approved healthcare services and practices to fight pandemics, even in cases of encrinites like the COVID-19 pandemic, is much invalid in the developing countries, in Tanzania in particular, where "indigenous medical practice continues to be the only source of therapy available to the majority of African peoples" [62] [and] "where a small proportion of trained healthcare personnel exists $(3 \%$ in sub-Saharan Africa) and about $80 \%$ of the population depends on traditional medicine for their primary healthcare needs [and western medicine] is not accessible to, or the first choice for, everyone" [63]. Certainly, African societies have been and shall continue using different preventive and curative approaches (African and western) to remedy perceived and real ill conditions.

\section{Conclusion and Recommendations}

Our presentation indicates that, historically, different African societies have managed different shocks including pandemics in different ways. In our perspective, African societies, and the Tanzanians in particular, are widely recognized to have strongly achieved the fight of pandemics using parallel existing systems: traditional therapy and biomedicine. COVID-19 is not a unique case. In practice, the use of multiple approaches battling coronavirus: biomedical, prayers, political fortitude and medicinal herbs are regarded to have, so far, prevented Tanzania from the severity of COVID-19. We note and recommend, Africa is rich with medicinal herbs known to treat various ill conditions and illnesses. It is recommended that African governments should adequately fund their respective Medical Research Units/Departments to conduct research into various aspects of African therapy and medical practices for the purpose of facilitating the development and application of medicinal herbs in the healthcare system in the continent and beyond. Similarly, we recommend that WHO should adhere to its vow of recognizing, welcoming and supporting innovations in African medicine for the development of new therapies and search for potential prevention, treatments and control of diseases including COVID19. Collaboration among WHO, Africa CDC, African governments, African Ministries of Health and National Medical Research Units/Departments should be strengthened for the development of trustworthy, affordable, effective and safe therapies for Africa, the developing world and even the developed world.

\section{Acknowledgements}

We acknowledge colleagues at the Muhimbili University of Health and Allied Sciences (MUHAS) for reading and commenting on earlier versions of this paper.

\section{References}

[1] Shereen, M. A., Khan, S., Kazmi, A., Bashir, N., Siddique, R. COVID-19 infection: Origin, transmission, and characteristics of human coronaviruses. COVID-19 infection: Origin, transmission, and characteristics of human coronaviruses. (2020). Available at: https://reader.elsevier.com/reader/sd/pii/S2090 123220300540?token=3FF23C7AA7725D4D8 06D0B2B4BFD3555A7C142BD9B8BE6CAA 048133F1055BF60AA351AD9765451204795 495711DAC8C5 Accessed on June 24, 2020.

[2] Rothan, H.A. and Byrareddy, S.N. The epidemiology and pathogenesis of coronavirus disease (COVID-19) outbreak. Journal of autoimmunity. 109:102433. (2020). https://www.sciencedirect.com/science/article/p ii/S0896841120300469 Accessed on June 24, 2020.

[3] World Health Organization (WHO). 2019-nCoV outbreak is an emergency of international concern. (2020a). Available at: http://www.euro.who.int/en/health- 
topics/emergencies/pages/news/new s/2020/01/2019-ncov-outbreak-is-anemergency-of-international-concern Accessed on February 16, 2020.

[4] Worldometer. COVID-19 Coronavirus Pandemic. (2020). Available at: https://www.worldometers.info/coronavirus/ Accessed on October 15, 2020.

[5] Khuroo, M. S., Khuroo, M., Khuroo, M. S. and Khuroo, N. S. COVID-19 vaccines: A race against time in the middle of death and devastation! J Clin Exp Hepatol. Jun 10. (2020). doi: 10.1016/j.jceh.2020.06.003. https://www.sciencedirect.com/science/article/p ii/S0973688320300906\#! Accessed on June 24, 2020.

[6] Guarascio F. United Nations (U.N.) calls for the COVID vaccine, treatment available for all. Reuters Health. Brussels. (2020). Available from https://in.reuters.com/article/us-healthcoronavirus-eu-virus-un/u-n-calls-for-covidvaccine-treatment-available-for-allidINKBN22G1MZ Accessed on June 24, 2020.

[7] Hellewell, J., Abbott, S., Gimma, A., Bosse, N. I., Jarvis, C. I., Russell, T. W., Munday, J. D., Kucharski, A. J., Edmunds, W. J. Centre for the Mathematical Modelling of Infectious Diseases COVID-19 Working Group, Funk, S. and Eggo, R. M. Feasibility of controlling COVID19 outbreaks by isolation of cases and contacts. The Lancet Global Health. (2020). Available at:

https://reader.elsevier.com/reader/sd/pii/S2214 109X20300747?token=6A9672C02EA7DD80 D11B6A03974EF5F920D43996ABC2F97C02 24E013D201A2033BD153D53D0467A9F0D7 FBAF1BF4D1B3 Accessed on June 24, 2020.

[8] Kombe, C. Tanzania Confirms First Case of Coronavirus. March 16. (2020a). Available at: https://www.voanews.com/science-

health/coronavirus-outbreak/tanzania-confirmsfirst-case-coronavirus_Accessed on May 19, 2020.

[9] Tairo, A. Tanzania COVID-19: Health Ministry confirms first case of coronavirus. eTN Tanzania. March 16. (2020). Available at: https://www.eturbonews.com/567287/tanzaniacovid-19-health-ministry-confirms-first-caseof-coronavirus/ Accessed on May 19, 2020.

[10] The Citizen. Tanzania bans all public gatherings, closes schools, suspends Premier League over Coronavirus. March 1. (2020). Accessed on May 25, 2020.

[11] Malanga, A. Tanzania Lifts Ban On International Flights. The Citizen (Dar es Salaam). May 19. (2020). Available at: https://allafrica.com/stories/202005190521.htm 1 Accessed on May 21, 2020.

[12] Africa News. God will help us, Tanzania president rejects virus lockdown. (2020). Available at: http://tanzania.shafaqna.com/EN/AL/39880 Accessed on May 21, 2020.

[13] Materu, B. Tanzania's 480 Covid-19 cases now the highest in the region. The East African. May 2. (2020). Available at: https://www.theeastafrican.co.ke/news/ea/Tanz ania-480-Covid19-cases-is-highest-in-eastafrica/4552908-5537840-f890orz/index.html Accessed on May 19, 2020.

[14] Tih, F. Madagascar leader urges use of supposed COVID-19 cure. Anadolu Agency. (2020). Available at: https://www.aa.com.tr/en/africa/madagascarleader-urges-use-of-supposed-covid-19cure/1844564 Accessed on May 25, 2020.

[15] Al Jazeera. Coronavirus: What is Madagascar's 'herbal remedy' Covid-Organics? May 5. (2020a). Available at: https://www.aljazeera.com/news/2020/05/coron avirus-madagascar-herbal-remedy-covidorganics-200505131055598.html Accessed on May 26, 2020.

[16] Ndegwa, S. Madagascar's COVID-19 herbal concoction re-ignites debate on herbal medicine in Africa. (2020). Available at: https://news.cgtn.com/news/2020-0506/Madagascar-s-CVO-re-ignites-debate-onherbal-medicine-in-Africa-Qgtwx9D1hC/index.html Accessed on May 26, 2020.

[17] FRANCE 24. Covid-19 in Madagascar: The president's controversial 'miracle cure'. (2020). Available at: https://www.france24.com/en/20200505-covid19-in-madagascar-the-president-scontroversial-miracle-cure Accessed on May 26, 2020.

[18] Solomon, S. No 'Miracle Cure' for Coronavirus Until Clinical Trials Prove Madagascar's Herbal Medicine. VOA. May 17. (2020). Available at: https://www.voanews.com/covid-19pandemic/no-miracle-cure-coronavirus-untilclinical-trials-prove-madagascars-herbal Accessed on May 26, 2020.

[19] Shaban, A. R. A. Comoros thanks Madagascar for supply of COVID-Organics. (2020). Available

at: https://www.africanews.com/2020/05/14/covidorganics-tanzania-comoros-opt-formadagascar-virus-cure// Accessed on May 25, 2020. 
[20] China Global Television Network (CGTN). COVID-Organics: Madagascar's purported cure for the pandemic. (2020). Available at: https://newsaf.cgtn.com/news/2020-05-

20/COVID-Organics-Madagascar-s-purportedcure-for-the-pandemic-

QD1d9NvecE/index.html May 20. Accessed on May 26, 2020.

[21] Al Jezeera. Tanzania gets Madagascar's anticoronavirus drink disputed by WHO. News Agencies. May 8. (2020b). Available at: https://www.aljazeera.com/news/2020/05/tanza nia-madagascar-anti-coronavirus-drinkdisputed-200508164354282.html Accessed on May 19, 2020.

[22] Burdon-Manley, L. WHO says Madagascar's herbal tonic against COVID-19 not a cure. Al Jazeera News. (2020). Available at: https://www.aljazeera.com/news/2020/05/mada gascars-herbal-tonic-covid-19-cure200504081212753.html?xif $=$ Accessed on May 26,2020

[23] The Citizen Reporter. Tanzania: COVID-19 Tanzania Collects Madagascar Herb. (2020). Available https://allafrica.com/stories/202005110260.htm 1 Accessed on May 19, 2020.

[24] Xinhua. Tanzania to conduct local clinical trials for Madagascar's COVID-19 herbal remedy. Xinhua (2020-05-10). (2020). Available at: http://www.xinhuanet.com/english/202005/10/c_139045603.htm Accessed on May 25, 2020.

[25] Kombe, C. Herbal Cures for COVID-19 Spreading in Tanzania Despite No Evidence They Work. VOA. May 22. (2020b). Available at: https://www.voanews.com/covid-19pandemic/herbal-cures-covid-19-spreadingtanzania-despite-no-evidence-they-work Accessed on May 26, 2020.

[26] Media Center. NIMR: Dawa Lishe ya Tanzaania inatibu dalili za awali za COVID-19. May 19. (2020). Available at: https://www.dw.com/sw/nimr-dawa-lishe-yatanzania-inatibu-dalili-za-awali-za-covid19/av-53499695 Accessed on June 1, 2020.

[27] Kimaro, V. "Nilikiona kifo, dawa ya NIMR imeniponya". HabariLeo. May 11. (2020a). Available at: https://habarileo.co.tz/habari/2020-05085eb4f7f85771c.aspx Accessed on June 1, 2020.

[28] Kimaro, V. ....Dawa kutoka NIMR yaonyesha mafanikio. (2020b). Available at: https://habarileo.co.tz/habari/2020-05085eb4f7f85771c.aspx Accessed on June 1, 2020.
[29] Nipashe. Dawa ya NIMR yatoa mwanga wagonjwa wa corona. May 10. IPPmedia. (2020).

https://www.ippmedia.com/sw/habari/dawa-yanimr-yatoa-mwanga-wagonjwa-wa-corona Accessed on June 1, 2020.

[30] Jamii Forum. Dawa ya NIMRCAF iliyoonyesha uwezo mkubwa wa kudhibiti virus vya corona mwili kujenga kinga dhidi ya magonjwa mengine. May 22. (2020). https://www.jamiiforums.com/threads/dawaya-nimrcaf-iliyoonesha-uwezo-mkubwa-wakudhibiti-virusi-vya-corona-pia-kuusaidiamwili-kujenga-kinga-dhidi-ya-magonjwamengine.1732928/ Accessed on June 1, 2020.

[31] Africa Check. Tanzania's President promotes steaming as alternative treatment for Coronavirus. (2020). Available at: https://www.ubuntutimes.com/tanzaniaspresident-promotes-steaming-as-alternativetreatment-for-coronavirus/ Accessed on June 17,2020 .

[32] Kuira. Waziri Jafo: "Tusione aibu kujifukiza". A truth. April 30. (2020). Available at: https://aftruth.com/swa/2020/04/30/waziri-jafotusione-aibu-kujifukiza/ Accessed on May 26, 2020.

[33] United Republic of Tanzania (URT). Viongozi Rukwa waendelea kuhamasisha matumizi ya Nyungu. May $3^{\text {rd }}$. (2020). Available at: http://www.rukwa.go.tz/new/viongozi-rukwawaendelea-kuhamasisha-matumizi-ya-nyungu Accessed on May 26, 2020.

[34] Kondwe, R. Tanzania's president is blaming the sharp rise of coronavirus cases on faulty testing kits. Quartz Africa. May 4. (2020a). Available at: https://qz.com/africa/1850839/tanzaniapresident-magufuli-blames-covid-19-rise-onfaulty-tests-goats/ Accessed on May 19, 2020.

[35] Al Jazeera. Tanzania COVID-19 lab head suspended as president questions data, May 5. (2020c). Available at: https://www.aljazeera.com/news/2020/05/tanza nia-covid-19-lab-head-suspended-presidentquestions-data-200505065136872.html Accessed on May 19, 2020.

[36] World Health Organization (WHO). WHO supports scientifically-proven traditional medicine. (2020b). Available at: https://www.afro.who.int/news/who-supportsscientifically-proven-traditional-medicine? Accessed on February 16, 2020.

[37] AllAfrica. Tanzania: What Do Jesus, Pawpaws and Goats Have to Do with Fighting COVID19 in Tanzania? (2020). Available at: https://allafrica.com/stories/202005060969.htm 1 Accessed on May 18, 2020. 
[38] Beaumont, P. Tanzania's president shrugs off Covid-19 risk after sending fruit for 'tests'. Global Development. 19 May. (2020). Available at: https://www.theguardian.com/globaldevelopment/2020/may/19/tanzanias-presidentshrugs-off-covid-19-risk-after-sending-fruitfor-tests Accessed on May 19, 2020.

[39] British Broadcasting Corporation (BBC) News. Coronavirus: Tanzania President Magufuli says hospital numbers reducing 17 May. (2020). Available at: https://www.bbc.com/news/world-africa52697508 Accessed on May 19, 2020.[40] Kitomary. Fact-checking Tanzanian president John Magufuli on inhaling steam to treat Covid-19. (2020) Available at: https://africacheck.org/reports/fact-checkingtanzanian-president-john-magufuli-on-inhalingsteam-to-treat-covid-19/ Accessed on June 15, 2020.

[41] Tanzania Broadcasting Cooperation Television (TBC, TV). Aridhio. May 30. (2020a). Dar-esSalaam.

[42] Odula, T. Tanzania's President Insists COVID19 Was Defeated With Prayer Amid Concerns Scale of Outbreak Being Hidden. Time. May 22. (2020a). Available at: https://time.com/5841441/tanzaniacoronavirus-defeated-prayer/ Accessed on May 25, 2020.

[43] Devermont, J. and Harris, M. 2020. Implications of Tanzania's Bungled Response to Covid-19. CSIS. May 26. Available at: https://www.csis.org/analysis/implicationstanzanias-bungled-response-covid-19

Accessed on June 1, 2020.

[44] Odula, T. Concerns about virus in Tanzania grow amid lack of data. Apne News. May 22. (2020b). Available at: https://apnews.com/9a0304b6798e8b0f635632 58d29c888e Accessed on May 22, 2020.

[45] Tanzania Broadcasting Cooperation. Television (TBC, TV). Aridhio. May 17. (2020b). Dar-es-Salaam.

[46] Mules, I. Tanzania under fire from WHO for lackluster response to COVID-19 pandemic. (2020). Available at: https://www.dw.com/en/tanzania-under-firefrom-who-for-lackluster-response-to-covid-19pandemic/a-53304699 Accessed on May 19, 2020.
[47] Kiruga, M. Coronavirus: Tanzania's handling of pandemic raises eyebrows. (2020). Available at:

https://www.theafricareport.com/27787/corona virus-tanzanias-handling-of-pandemic-raiseseyebrows/ Accessed on May 19, 2020.

[48] Kondwe, R. Tanzania's president is under pressure after three MPs die in 11 days and Covid-19 cases spike. (2020b). Available at: https://qz.com/africa/1849684/tanzaniasmagufuli-panned-as-covid-19-cases-jumpthree-mps-die/ Accessed on May 19, 2020.

[49] Boniphace, E. Tanzania hiding true number of Covid deaths, opposition says. (2020a). Available at: https://www.ft.com/content/64521099-08504b94-b918-c302ada63916 Accessed on May 19, 2020.

[50] Boniphace, E. Tanzania opposition angry over no coronavirus update in two weeks. AFP News Agency. May 13. (2020). Available at: https://www.aljazeera.com/news/2020/05/tanza nia-opposition-angry-coronavirus-updateweeks-200513133059614.html Accessed on May 19, 2020.

[51] Chahali, E. Tanzania: How long can its COVID-19 strategy hold? (2020). Available at: https://africanarguments.org/2020/05/18/tanzan ia-how-long-can-its-covid-19-strategy-hold/ Accessed on May19, 2020.

[52] Mdoe, G, Coronavirus update: Tanzania cases reach 480, neighbouring countries close borders. (2020). Available at: https://theexchange.africa/countries/tanzania/co ronavirus-update-tanzania-ases-reach-480neighbouring-countries-close-borders/ Accessed on May 19, 2020.

[53] Kamazima, S. R., Kazaura, M. and Kakoko, D. C. V. From Hospitality to Hostility: Border Crossing Experiences among Unsung Heroes on the Wheel in COVID-19-Hit East Africa. IJASRM. 5(9):143-157. ISSN 24556378. (2020).

[54] The Daily Nation. Zambia closes border with Tanzania to tame Covid-19. May 11. (2020). Available at: https://www.monitor.co.ug/News/National/Za mbia-closes-border-with-Tanzania-to-tameCovid-19/688334-5548676-jknarf/index.html Accessed on May 19, 2020.

[55] Vuzo, S. How COVID-19 is changing the lives of Tanzanians. (2020). May 23. Available at: https://www.un.org/africarenewal/webfeatures/coronavirus/how-covid-19-changinglives-tanzanian Accessed on June 2, 2020.

[56] Kamazima, S. R., Kazaura, M. R., Kwesigabo, N. P., Joram, J. T. and Kamazima, B. K. Okwelokola: A modern form of slavery, 
exploitation, human rights violation and mother of poverty among the poor Bahaya in Kagera Region, Tanzania. IJCIR. 4(2):1049-1056. (2018).

[57] Chirikure, S. How ancient African societies used social distancing to manage pandemics. May 18. (2020). Available at: https://qz.com/africa/1858278/how-ancientafrican-societies-managed-pandemics-likespanish-flu/ Accessed on May 19, 2020.

[58] Kamazima, S. R. Borders, Boundaries, Peoples and States: A Comparative Analysis of Potindependence Tanzania-Uganda border Regions. PhD Thesis. University of Minnesota. (2003).

[59] White, L. Comforts of Home: Prostitution in Colonial Nairobi. Chicago. University of Chicago Press. (1990).

[60] Mukherjee, A. Economic life after Covid-19: Lessons from the Black Death. (2020).
Available at: https://www.bloomberg.com/opinion/articles/2 020-03-29/economic-life-after-covid-19lessons-from-the-black-death Accessed on October 19, 2020

[61] Wikipedia.org, nd. Black Deth. (nd.). Available at: Available at: http://taggedwiki.zubiaga.org/new_content/f36 08b7717eb962b911ed16b073defe8 Accesssed on June 24, 2020.

[62] du Toit, B. M. and Abdalla, I. H. African healing strategies. Trado-Medic Books. (1985).

[63] Dhwty. Traditional African Medicine and its Role in Healing in a Modern World. (2015). http://www.ancientorigins. net/history-ancient-traditions/traditionalafrican-medicine-and-its-role-healing-modernworld-004522. Accessed May 2020. 